\title{
PENGEMBANGAN LEMBAR KERJA SISWA BERBASIS MULTIPLE INTELLIGENCE PADA MATERI ENZIM SISWA SMA
}

\author{
Anista Vera Duwi Lestari ${ }^{1}$, Khoirun Nisa ${ }^{2}$ \\ ${ }^{1,2}$ Program Studi Pendidikan Biologi IKIP Budi Utomo \\ Jl. Simpang Arjuno 14B Malang \\ e-mail: anistayosialestari@yahoo.com
}

\begin{abstract}
This research was conducted based on the problems that occurred, among others: LKS owned by students so far have not been able to train students to learn independently and low mastery of students on metabolic material. The purpose of this development research is to find out the development process and find out the results of the development of Multiple Intelligence Based Student Worksheets on the material of high school students' enzymes. This study uses the 4D development model by Thiagarajan et al. which includes 4 stages: Define, design, design and Disseminate. Testing of Multiple Intelligence-Based LKS products, there are several aspects including media assessment, assessment of material and readability tests. Multiple Intelligence-based worksheet validation results have been obtained by media expert validators with a percentage of $96.43 \%$, by the material expert validator with a percentage of $84.21 \%$ and the students' readability trial results obtained a percentage of $65.33 \%$. Based on the data that has been obtained for testing this Multiple Intelligence-Based LKS product, it is expected that in the future it can be tested on a large scale in the classroom for further development. Further development, can be done with classroom action training (PTK) or Experimental research.
\end{abstract}

Keywords: worksheets, Multiple Intelligence.

\section{PENDAHULUAN}

Pendidikan merupakan salah satu modal terpenting bagi masyarakat yang tinggal di Negara berkembang seperti Negara Indonesia. Namun, masih banyak permasalahan pendidikan di Indonesia yang saat ini masih belum terselesaikan oleh pemerintah serta pendidik-pendidik di seluruh Indonesia. Permasalahan yang sering terjadi dalam dunia pendidikan, lebih banyak berasal dari faktor internal.

Hal serupa juga disampaikan Muhardi (2004) bahwa pendidikan merupakan investasi jangka panjang yang sangat berharga dan bernilai luhur, terutama bagi generasi muda yang akan menentukan maju mundurnya suatu bangsa.
Hal demikian juga disampaikan Dalam penelitian Srinalia (2015) yang menyatakan bahwa telah ditemukan permasalahan pendidikan pada SMA 1 Darul Imarah Aceh Besar yang berasal dari faktor internal yaitu guru yang sering melanggar tata tertib sekolah dan kurang disiplin hadir di sekolah serta dalam perencanaan pembelajaran.

Banyak guru yang kurang terbiasa menggunakan media pembelajaran juga mempengaruhi kelancaran proses belajar di dalam kelas. Guru ingin lebih praktis dalam mengajar dengan menggunakan metode lama yaitu dengan metode ceramah. Selain itu, guru juga masih belum secara maksimal menggunakan media pembelajaran (Setiawan, 
H.R., 2016).

Media pembelajaran LKS yang dimiliki oleh siswa selama ini belum mampu melatih siswa dalam belajar secara mandiri karena didalam LKS tersebut berisi soal-soal yang bisa dijawab dengan melihat materi yang terdapat pada LKS, dan masalah selanjutnya LKS yang digunakan siswa sebelumnya, kurang melatih siswa dalam menerapkan kecerdasan yang dimilikinya (Tanjung, dkk., 2017).

Lembar Kerja Siswa (LKS) adalah bahan ajar cetak yang berisi ringkasan, materi, dan petunjuk-petunjuk kerja dari soal yang harus dikerjakan oleh siswa sesuai dengan Kompetensi Dasar yang harus dicapai. Tugas-tugas yang diberikan kepada siswa dapat berupa teori atau praktik (Prastowo, 2012: 204).

Menurut Trianto (2009:222) adalah panduan siswa berupa bahan cetak yang digunakan untuk melakukan kegiatan penyelidikan atau memecahkan masalah. Lembar kerja siswa dapat berupa panduan untuk pengembangan semua aspek pembelajaran maupun panduan untuk latihan pengembangan aspek kognitif dalam bentuk demonstrasi atau panduan eksperimen.

Lembar Kegiatan Siswa (student worksheet) menurut Depdiknas 2008 merupakan lembaran-lembaran berisi tugas yang harus dikerjakan oleh peserta didik. Lembar kegiatan biasanya berupa petunjuk, langkah-langkah untuk menyelesaikan suatu tugas. Suatu tugas yang diperintahkan dalam lembar kegiatan harus jelas sesuai dengan $\mathrm{KD}$ yang akan dicapainya.

Pendapat lain mengatakan, bahwa LKS berisi tentang materi, ringkasan, dan tugas yang berkaitan dengan materi. Dalam LKS terdapat arahan yang terstruktur untuk siswa, sehingga dapat memahami materi yang diberikan (Belawati, 2003).
Permasalahan lain, pada kegiatan belajar mengajar siswa menganggap dalam mempelajari mata pelajaran Biologi lebih cenderung menghafal dibandingkan harus dimengerti. Hal ini terbukti melalui kegiatan pembelajaran yang dilakukan siswa yang lebih cenderung mendengarkan penjelasan dari guru dan mencatat (Solikhatun, dkk., 2015).

Menurut Kose (2008, dalam Muspikawijaya, dkk., 2017) tentang permasalahan rendahnya penguasaan peserta didik pada materi metabolisme diduga karena peserta didik mengalami kesulitan belajar. Peserta didik kesulitan dalam memahami konsep enzim, respirasi sel dan fotosintesis karena melibatkan berbagai konsep dasar seperti biokimia, anatomi-fisiologi, perubahan energi serta molekul organik dan anorganik untuk memahami sifat kimia respirasi dan fotosintesis.

Manusia mempunyai kecerdasan yang berbeda-beda untuk memecahkan masalah salah satunya untuk belajar sesuatu hal yang baru. Begitupun dengan siswa, mereka mempunyai kecerdasan yang berbeda dengan siswa lainnya untuk mempelajari pengetahuan baru yang didapat dalam mata pelajaran khususnya Biologi.

Nurdin (2005 dalam Hadi, 2017) menyatakan bahwa telah menjadi keyakinan semua orang pada masing-masing individu memiliki karakteristik kemapuan yang berbeda-beda. Ada yang berkemampuan cepat, sedang, dan ada yang berkemampuan rendah. Menurut tinjauan psikologis setiap anak memiliki perbedaan dengan lainnya. "Tak ada dua orang di dunia ini yang benarbenar sama dalam segala hal, sekalipun mereka kembar".

Gardner berpendapat bahwa kecerdasan adalah suatu kemampuan untuk memecahkan masalah dan menghasilkan 
sebuah produk dalam situasi yang nyata. Sehingga dapat dikatakan bahwa Multiple Intelligence atau kecerdasan majemuk adalah berbagai macam keterampilan dan bakat yang dimiliki individu untuk menyelesaikan berbagai persoalan dalam pembelajaran (Suparno, 2004).

Kecerdasan majemuk menurut penemuan Howard Gardner meliputi: a). kecerdasan verbal-linguistik, b). kecerdasan logis-matematis, c). kecerdasan visualspasial, d). kecerdasan berirama-musik, e). kecerdasan jasmaniah-kinestetik, f). kecerdasan interpersonal, g). kecerdasan intrapersonal, h). kecerdasan naturalistik, dan i). kecerdasan eksistensial-spiritual (Suparno. 2004).

Berdasarkan latar belakang di atas, maka dilakukan penelitian Pengembangan Lembar Kerja Siswa Berbasis Multiple Intelligences Pada Materi Enzim Siswa SMA. Penelitiaan ini bertujuan untuk mengetahui proses pengembangan dan mengetahui produk hasil pengembangan Lembar Kerja Siswa Berbasis Multiple Intelligence pada materi enzim siswa SMA.

\section{METODE PENELITIAN}

Penelitian ini menggunakan model pengembangan 4D oleh Thiagarajan dkk. yang meliputi 4 tahapan yaitu: Define, Design, develop dan Disseminate. Alur dari tahapan model 4D dapat dillihat pada Gambar 1. Tahap define, dilakukan analisis pada media pembelajaran, kondisi siswa, dan pembelajaran Biologi untuk menetukan analisis konsep dan perumusan tujuan pembelajaran. Tahapan design, dilanjutkan dengan pemilihan media yang akan dikembangkan, memilih format yang akan digunakan untuk mendesain media pembelajaran dan menghasilkan rancangan awal berupa draf media pembelajaran.
Tahapan selanjutnya yaitu tahapan develop, dengan melakukan validasi produk oleh ahli media dan ahli materi melalui angket. Setelah draf I divalidasi dan direvisi, maka dihasilkan draf II. Draf II selanjutnya akan diujikan kepada siswa dalam tahap uji coba skala kecil sebanyak 5 orang. Tahapan disseminate tidak dilakukan karena keterbatasan waktu dan biaya.

Intrumen yang digunakan untuk mengumpulkan data yaitu lembar angket. Peneliti membuat lembar angket untuk validator yang terdiri dari dosen ahli media, dosen ahli materi dan siswa. Angket ini berisi pertanyaan yang akan menjelaskan indikator yang akan diukur untuk LKS berbasis Multiple Intelligence. Jawaban dari angket ini menggunakan skala Likert yang terdiri dari 4 kategori pilihan yaitu 4 artinya sangat baik, 3 artinya baik, 2 artinya kurang, dan 1 artinya sangat kurang.

Teknik analisis data pada penelitian berhubungan dengan jenis data terdiri dari 2 yaitu data kualitatif dan data kuantitatif. Data kualitatif pada penelitian diperoleh melalui hasil komentar, saran dan tanggapan dari dosen sebagai validator maupun siswa yang melakukan uji coba keterbacaan terhadap LKS Berbasis Multiple Intelligence.

Sedangkan untuk data kuantitatif diperoleh melalui angket yang menggunakan angka Likert dan menganalisis dengan analisis persentase.

Berikut ini adalah rumus penilaian data kuantitatif dengan analisis persentase.

Keterangan:

$$
\mathrm{P}=\mathrm{y} \text { vi } 100 \%{ }^{y} i^{i}
$$

$\mathrm{P}=$ Persentase pilihan

$\mathbf{y x i}=$ Jumlah jawaban penilaian oleh ahli

$\mathbf{y x j}=$ Jumlah jawaban tertinggi maksimal 
Gambar 1 Model Pengembangan 4D oleh Thiagarajan dkk.

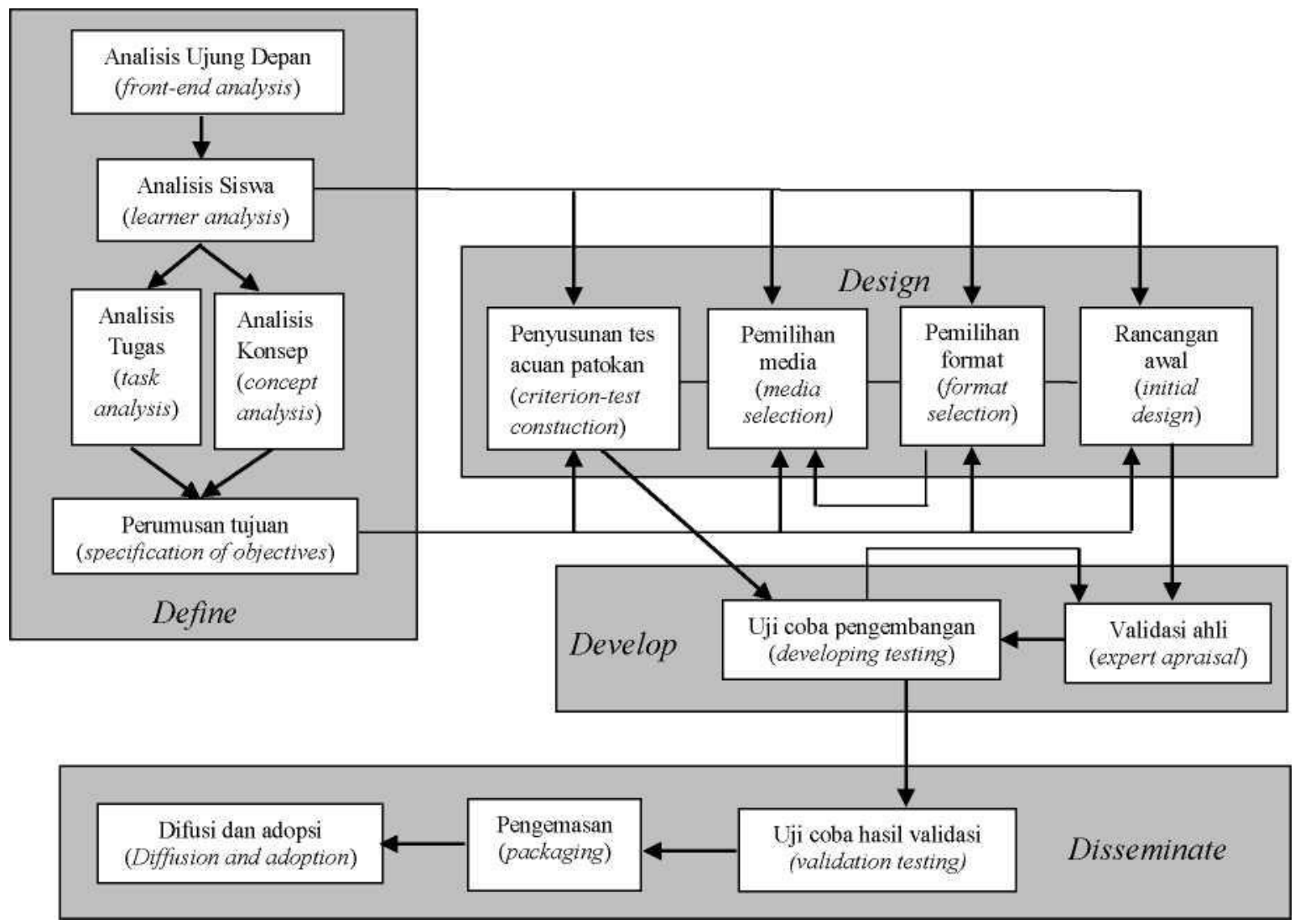

Hasil dari data analisis persentase yang diperoleh akan dibandingkan dengan jenjang kualifikasi penilaian instrumen pada Tabel 1

Tabel 1. Jenjang Kualifikasi Penilaian Instrumen

\begin{tabular}{|c|c|c|c|c|c|c|}
\hline $\begin{array}{c}\text { Taraf } \\
\text { Penguasaan } \\
\text { Kemampuan* } \\
\end{array}$ & $\begin{array}{c}\text { Nilai } \\
\text { Huruf*** }\end{array}$ & $\begin{array}{c}\text { Taraf } \\
\text { Penguasaan } \\
\text { Persentase }(\%)\end{array}$ & $\begin{array}{l}\text { Nilai } \\
\text { Huruf }\end{array}$ & $\begin{array}{c}\text { Keterangan } \\
\text { Huruf }\end{array}$ & $\begin{array}{l}\text { Kriteria } \\
\text { Validitas } \\
\end{array}$ & Keterangan \\
\hline $\begin{array}{c}91-100 \\
84-90\end{array}$ & $\begin{array}{l}\text { A } \\
\text { A- }\end{array}$ & $84-100$ & A & Sangat Baik & Valid & Tidak Revisi \\
\hline $\begin{array}{l}77-83 \\
71-76 \\
66-70 \\
61-65 \\
\end{array}$ & $\begin{array}{l}\mathrm{B}+ \\
\mathrm{B} \\
\mathrm{B}- \\
\mathrm{C}+\end{array}$ & $62-<84$ & B & Baik & $\begin{array}{l}\text { Cukup } \\
\text { Valid }\end{array}$ & Revisi \\
\hline $\begin{array}{l}55-60 \\
41-54 \\
\end{array}$ & $\begin{array}{l}\mathrm{C} \\
\mathrm{D} \\
\end{array}$ & $41-<61$ & $\mathrm{C}$ & Kurang Baik & $\begin{array}{l}\text { Kurang } \\
\text { Valid }\end{array}$ & Revisi \\
\hline $0-40$ & $\mathrm{E}$ & $<41$ & $\mathrm{D}$ & Tidak Baik & $\begin{array}{l}\text { Tidak } \\
\text { Valid }\end{array}$ & Revisi \\
\hline
\end{tabular}

*) Taraf Penguasaan Kemampuan berdasarkan Pedoman Pendidikan UM dalam Setiawan (2012: 36)

**) Nilai Huruf berdasarkan Pedoman Pendidikan UM dalam Setiawan (2012: 36)

\section{HASIL DAN PEMBAHASAN}

\section{Tahapan Define}

Berdasarkan hasil analisis yang telah dilakukan, masih belum terdapat media pembelajaran yang dapat mengatasi rendahnya penguasaan pada mata pelajaran Biologi, khususnya materi Enzim. Berdasarkan analisis ini, peneliti memilih 
materi Enzim yang akan digunakan pada media pembelajaran yang dikembangkan. Berikut ini adalah Kompetensi Inti 4. Mengolah, menalar, menyaji, dan mencipta dalam ranah konkret dan ranah abstrak terkait dengan pengembangan dari yang dipelajarinya di sekolah secara mandiri serta bertindak secara efektif dan kreatif, dan mampu menggunakan metode sesuai kaidah keilmuan serta Kompetensi Dasar 4.2. Melaksanakan percobaan dan menyusun laporan hasil percobaan tentang cara kerja enzim, fotosintesis, respirasi anaerob secara tertulis dengan berbagai media.

Kemudian, peneliti menentukan tujuan pembelajaran sesuai dengan indikator yang telah dibuat pada hasil analisis konsep. Poin-poin penting dari materi enzim yang terdapat pada indikator antara lain: pengertian enzim, komponen penyusun enzim, sifat-sifat enzim, model kerja enzim dan faktor-faktor yang mempengaruhi kerja enzim. Setelah itu, peneliti dapat menentukan soal-soal yang akan dicantumkan pada media pembelajaran.

Soal-soal ini lebih cenderung, siswa bekerja sendiri untuk mencari informasi tentang materi Enzim. Hal ini sependapat dengan Yaumi (2012, dalam Risdawati, dkk., 2017) yang menyatakan bahwa pada kegiatan pembelajaran, siswa berperan sebagai agent kognitif yang didistribusikan antara pendidik dan peserta didik. Siswa dapat mencari cara dan metode untuk mencapai tujuan, menyusun tujuan dan melibatkan diri secara langsung untuk melaksanakan kegiatan pembelajaran serta melakukan evaluasi diri dari hasil yang diperoleh.

\section{Tahapan Design}

Media pembelajaran yang digunakan dalam penelitian pengembangan adalah LKS Berbasis Multiple Intelligence yang dibuat dengan 9 macam jenis LKS. Hal ini disesuaikan dengan banyaknya kecerdasan majemuk
(Multiple Intelligence) yang telah ditemukan oleh Howard Gardner antara lain: a). kecerdasan verbal-linguistik, b). kecerdasan logis-matematis, c). kecerdasan visual-spasial, d). kecerdasan berirama- musik, e). kecerdasan jasmaniahkinestetik, f). kecerdasan interpersonal, g). kecerdasan intrapersonal, h). kecerdasan naturalistik, dan i). kecerdasan eksistensialspiritual (Suparno, 2004).

$$
\text { Pembuatan LKS ini sangat }
$$

memperhatikan penyusunan materi sehingga lebih sistematis. Selain segi estetika dari LKS tersebut, model soal yang dibuat juga sangat bermacam- macam antara lain siswa dianjurkan untuk mencari jawaban dari berbagai sumber (misalnya: buku dan internet), menyusun kata, menyusun huruf, menebak kata melalui clue (petunjuk), menggambar, menyusun gambar, melengkapi kalimat, membuat lirik lagu dari materi Enzim, dan melakukan praktikum. Sedangkan untuk soal evaluasi menggunakan model soal seperti TTS, kuis mencari kata, dan membuat flipbook.

Pada rancangan awal, LKS dibuat sesuai dengan struktur LKS yang mengacu pada Depdiknas 2010 yang memuat: a). judul/ identitas, b). petunjuk belajar, c). KD dan indikator, d). materi pembelajaran, e) langkah pembelajaran/ kerja, dan f). penilaian.

\section{Tahapan Develop}

Data tersebut diperoleh dari hasil angket validasi ahli dan uji keterbacaan. Berdasarkan hasil validasi LKS Berbasis Multiple Intelligence yang dilakukan dosen ahli media meliputi aspek kelayakan media, desain cover, isi dan struktur LKS telah diperoleh hasil persentase sebesar 96,43\%. Selain itu, hasil validasi terdapat kekurangan dari bahan LKS Berbasis Multiple Intelligence ini, yaitu: "Bisaditambahkan gambar yang mewakili dari tiap materi serta kualitas gambar yang jelas (HD)". 


\section{LKS Kecerdasan Linguistik}

Dibawah ini adalah salah satu soal dari LKS kecerdasan linguistik yaitu menyusun kata. Soal ini disesuaikan dengan kecerdasan linguistik, yang pada dasarnya seseorang yang memiliki kecerdasan ini mampu mengolah kata atau kemampuan menggunakan kata secara efektif baik secara lisan maupun tertulis.

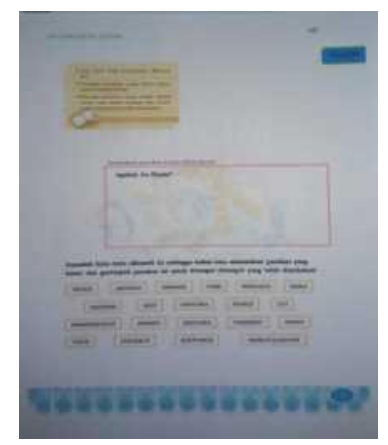

\section{LKS Kecerdasan Logika}

Dibawah ini adalah salah satu soal dari LKS kecerdasan logika yaitu menebak kata melalui clue. Soal ini disesuaikan dengan kecerdasan logika, yang lebih cenderung melibatkan kemahiran menggunakan logika atau akal sehat.

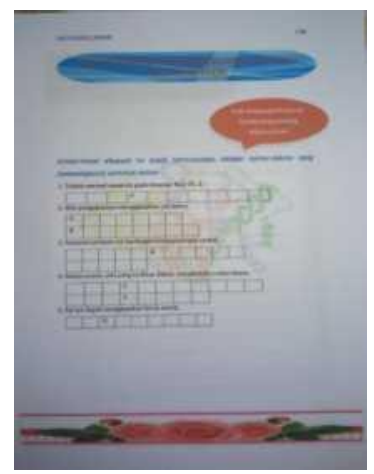

\section{LKS Kecerdasan Spasial Visual}

Dibawah ini adalah salah satu soal dari LKS Kecerdasan spasial visual yaitu mencari gambar. Soal ini disesuaikan dengan kecerdasan spasial visual, yang lebih berpikir dalam bentuk gambar dan visualisasi untuk menemukan jawaban atau memecahkan sesuatu masalah.

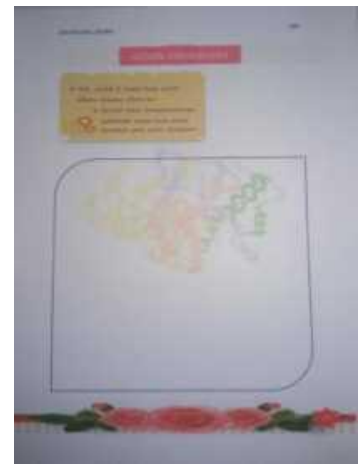

4. LKS Kecerdasan Kinestetik

Dibawah ini adalah salah satu soal dari LKS kecerdasan kinestetik yaitu bermain peran. Soal ini disesuaikan dengan kecerdasan kinestetik, dimana seseorang mampu atau terampil menggunakan anggota tubuhnya.

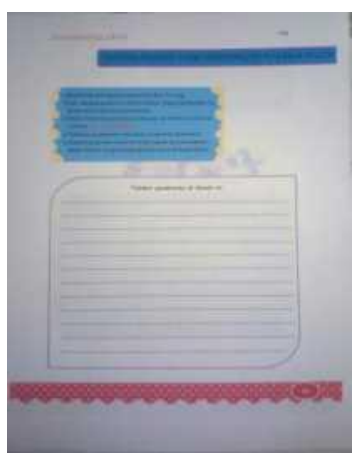

\section{LKS Kecerdasan Musikal}

Dibawah ini adalah salah satu soal dari LKS kecerdasan musikal yaitu membuat lirik lagu. Soal ini disesuaikan dengan kecerdasan musikal, yang mempunyai kemampuan memahami aneka bentuk kegiatan musikal dengan cara mengekspresikan (penyanyi), mengubah (komposer), membedakan (kritikus musik), dan mempersepsi (penikmat musik).

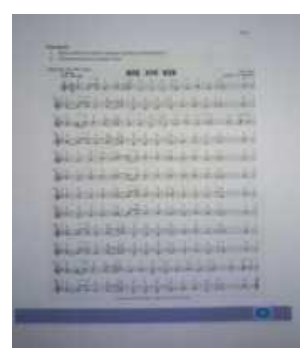




\section{LKS Kecerdasan Interpersonal}

Dibawah ini adalah salah satu soal dari LKS kecerdasan interpersonal yaitu menjawab pertanyaan melalui kerjasama dengan teman. Soal ini disesuaikan dengan kecerdasan interpersonal, dimana seseorang berpikir lewat berkomumikasi dan berinteraksi dengan orang lain.

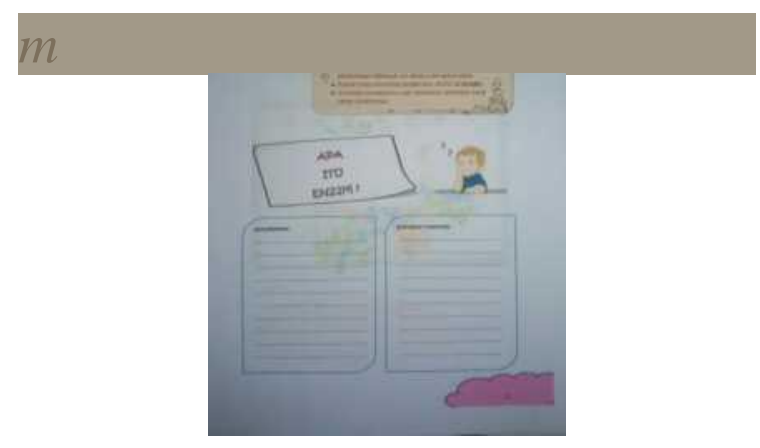

\section{LKS Kecerdasan Intrapersonal}

Dibawah ini adalah salah satu soal dari LKS kecerdasan intrapersonal yaitu menjawab pertanyaan secara mandiri. Soal ini disesuaikan dengan kecerdasan intrapersonal, dimana kemampuan seseorang untuk berpikir secara reflektif, yaitu mengacu pada kesadaran reflektif mengenai perasaan dan proses pemikiran diri sendiri.

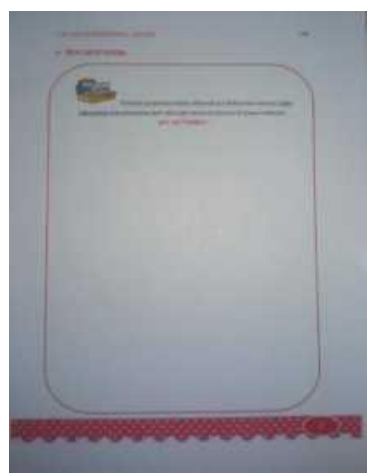

\section{LKS Kecerdasan Naturalis}

Dibawah ini adalah salah satu soal dari LKS kecerdasan naturalis yaitu melakukan praktikum. Soal ini disesuaikan dengan kecerdasan naturalis, dimana dapat dikembangkan melalui program kurikulum:

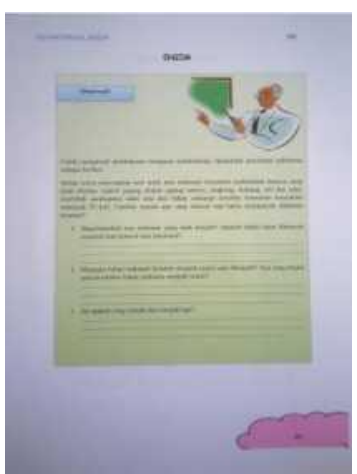

sains permulaan, ilmu botani, gejala-gejala alam, atau hubungan antara benda-benda hidup dan tak hidup yang ada di alam sekitar.

\section{LKS Kecerdasan Spiritual}

Dibawah ini adalah salah satu soal dari LKS kecerdasan spiritual yaitu menjawab

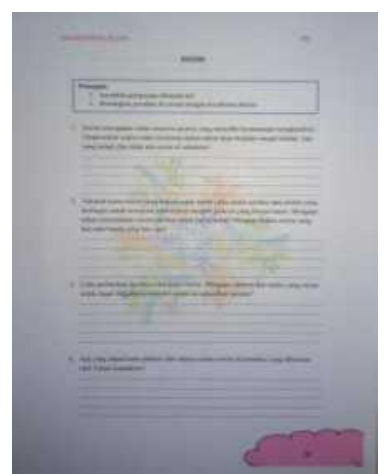

pertanyaan melalui perenungan. Soal ini disesuaikan dengan kecerdasan spiritual, yaitu kecerdasan untuk menghadapi dan memecahkan persoalan nilai dan makna.

Berdasarkan hasil validasi yang dilakukan oleh validator, telah diperoleh hasil analisis persentase pada Tabel 2 . 
Tabel 2. Hasil Analisis Validator untuk LKS Berbasis Multiple Intelligence

\begin{tabular}{ccc}
\hline & \multicolumn{2}{c}{ Analisis Persentase } \\
\hline Validator & Persentase & $\begin{array}{c}\text { Keterangan } \\
\text { Huruf }\end{array}$ \\
\hline
\end{tabular}

Primadya Anantyarta, $\quad 96,43 \quad$ Sangat Baik
S.Si., S.Pd., M.Pd. *

Erfitra Resqi Prasmala, $\quad 84,21 \quad$ Sangat Baik S.Pd., M. Pd. **

$\begin{array}{lrr}\text { Rata-rata } & \mathbf{9 0 , 3 2} & \text { Sangat Baik } \\ * \text { Validator Ahli Media } * * \text { Validator } & \text { Ahli Materi }\end{array}$

Kesimpulannya, rata-rata hasil analisis persentase dari validator ahli media dan materi adalah 90,32 dengan kriteria "valid" dan tidak perlu dilakukan revisi.

Berdasarkan hasil uji coba yang dilakukan oleh siswa, telah diperoleh hasil analisis persentase pada Tabel 3 .

Tabel 3. Hasil Analisis Uji Coba Keterbacaan Siswa untuk LKS Berbasis Multiple Intelligence

Analisis Persentase

\begin{tabular}{clcc}
\hline No & Siswa & Persentase & $\begin{array}{c}\text { Ketrangan } \\
\text { Huruf }\end{array}$ \\
\hline 1 & $\begin{array}{l}\text { Lenina Islami } \\
\text { Arnestya } \\
\text { Guevara } *\end{array}$ & 68,33 & Baik \\
\hline 2 & $\begin{array}{l}\text { Ramadhan Rahma } \\
\text { Azizah ** }\end{array}$ & 58,33 & Kurang Baik \\
\hline 3 & $\begin{array}{l}\text { Putri Galuh } \\
\text { Tribuana ** }\end{array}$ & 65,00 & Baik \\
\hline 4 & $\begin{array}{l}\text { Bratanti Suwita } \\
\text { Ningrum ** }\end{array}$ & 75,00 & Baik \\
\hline 5 & $\begin{array}{l}\text { Kartika Zita } \\
\text { Maharani ** }\end{array}$ & 60,00 & Kurang Baik \\
\hline & Rata-rata & $\mathbf{6 5 , 3 3}$ & Baik \\
\hline
\end{tabular}

* Siswa yang melakukan uji coba tersebut tahun 2018 baru naik kelas XI

** Siswa yang melakukan uji coba tersebut tahun 2018 baru naik kelas XII

Kesimpulannya, rata-rata hasil analisis persentase dari uji coba keterbacaan siswa adalah 65,33 dengan kriteria "cukup valid" dan masih perlu dilakukan revisi.
Hasil serupa juga didapatkan oleh Bariroh, dkk. (2014) bahwa hasil uji coba keterbacaan siswa terhadap LKS IPA Terpadu diperoleh persentase siswa sebesar $72 \%$. Tetapi setelah kegiatan pembelajaran dilaksanakan dengan menggunakan media berupa LKS IPA Terpadu yang dikembangkan oleh peneliti dengan tema polusi cahaya menggunakan keterpaduan tipe Webbed diperoleh persentase sebesar $91 \%$.

\section{SIMPULAN DAN SARAN}

Berdasarkan hasil validasi yang telah dilakukan oleh validator, produk LKS Berbasis Multiple Intelligence dapat dikategorikan sangat baik dan sudah dapat digunakan didalam pembelajaran.

Saran pemanfaatan produk ini, waktu yang dibutuhkan siswa untuk mengerjakan soal-soal LKS Berbasis Multiple Intelligence lebih lama dibandingkan dengan LKS secara umum. Jadi, apabila guru ingin melakukan kegiatan pembelajaran menggunakan LKS Berbasis Multiple Intelligence ini, sebelumnya harus merencanakan waktu agar efisien dan tepat waktu sehingga sesuai dengan alokasi waktu yang direncanakan. Selain itu, perlu dipertimbangkan untuk lokasi sekolah di daerah pedesaan yang akan menerapkan produk ini karena LKS ini lebih menekankan ke digital dalam mengerjakan soal-soal. Secara otomatis, sekolah yang menggunakan produk ini harus mempunyai sinyal internet yang bagus.

\section{RUJUKAN}

Bariroh, S.L., Muchlis. \& Fauziah, A.N.M. 2014. Pengembangan Lembar Kerja Siswa (LKS) IPA Terpadu Berbasis Pembelajaran Berdasarkan Masalah Tema Polusi 
Cahaya Kelas VIII MTs Negeri Ngronggot Nganjuk. Jurnal Pendidikan Sains e-Pensa. (Online), 2 (1): 123-128, (https://media.neliti.com), diakses 4 November 2018.

Depdiknas. 2008. Panduan Pengembangan Bahan Ajar. Jakarta: Depdiknas Prastowo, A. 2012. Panduan Kreatif Membuat Bahan Ajar Inovatif. Jogjakarta: Diva Press.

Depdiknas. 2010. Juknis Pengembangan Bahan Ajar. Jakarta: Direktorat Pembinaan Sekolah Menengah Atas.

Gardner, H. 1993. Multiple Intteligence: The Theory in Practice A Reader. USA: Basic Book.

Hadi, I.A. 2017. Pentingnya Pengenalan Tentang Perbedaan Individu Anak Dalam Efektivitas Pendidikan. Jurnal Inspirasi, (Online), 1 (1): 71-92,

(https://ejournal.undaris.ac.id), diakses 4 November 2018.

Muhardi. 2004. Konstribusi Pendidikan Dalam Meningkatkan Kualitas Bangsa Indonesia. Mimbar Jurnal Sosial Dan Pembangunan, (Online), 20 (4): 478-492, (https://ejournal.unisba.ac.id), diakses 4 November 2018.

Muspikawijaya., Iswari, R.S. \& Marianti, A. 2017. Analisis Kesulitan Peserta Didik SMA/MA Kabupaten Luwu Timur dalam Memahami Konsep pada Materi Metabolisme Sel. Journal of Innovative Science Education, (Online), 6 (2): 252-263, (https://journal.unnes.ac.id/sju/inde x.php/jise/article/view/15439), diakses 29 Juli 2018.
Risdawati., Mustami, M.K. \& Hamansah. 2017. Pengaruh Model Pembelajaran Concept Attainment Terhadap Aktivitas dan Hasil Belajar Biologi Siswa di Kelas XI IPA SMAN 11 Bulukumba. Jurnal Biotek, (Online), 5 (2): 158-177, (http://journal.uinalauddin.ac.id/index.php/biotek/a rticle/view/4286), diakes 18 Juli 2018.

Setiawan, D. 2012. Pengembangan Instrumen Penulisan Jurnal Belajar Berbasis ICT (Information, Communication, Technology) pada Pembelajaran Biologi Siswa Sekolah Menengah Atas. Skripsi tidak diterbitkan. Malang: FMIPA UM.

Setiawan, H.R. 2016. Problematikan dan Solusi Pemanfaatan Media Pembelajaran. Medan: Harian Medan Pos.

Solikhatun, I., Santosa, S. \& Maridi. 2015. Pengaruh Penerapan Reality Based Learning terhadap Hasil Belajar Biologi Siswa Kelas X SMA Negeri 5 Surakarta Tahun Pelajaran 2012/2013. Jurnal Pendidikan Biologi, (Online), 7 (3): 49-60,

(https://media.neliti.com), diakses 16 Agustus 2018.

Srinalia. 2015. Faktor-Faktor Penyebab Rendahnya Kinerja Guru Dan Kolerasinya Terhadap Pembinaan Siswa: Studi Kasus di SMAN 1 Darul Imarah Aceh Besar. Jurnal Ilmiah DIDAKTIKA, (Online), 15 (2): 193207, (https://www.neliti.com), diakses 4 November 2018.

Suparno, P. 2004. Teori Inteligensi Ganda dan Aplikasinya di Sekolah. Yogyakarta: Penerbit Kanisius. 
Tanjung, A.W.B., Lestari, R. \& Brahmana,

E.M. 2017. Pengembangan

Lembar Kerja Siswa (LKS)

Berbasis Multiple Intelligences

untuk Kelas VIII SMP Materi

Pertumbuhan dan Perkembangan.

E-Journal Mahasiswa Prodi

Biologi, (Online), 3 (1): 1-6,

(http://e-

iournal.upp.ac.id/index.php/fkipb

iologi/article/view/1223), diakses 6

Februari 2018.

Thiagarajan, S., Semmel, D.S. \& Semmel,

M.I. $1974 . \quad$ Instructional

Development for Training

Teachers of Exceptional Children.

Indiana: Indiana University

Bloomington.

Trianto. 2009. Mendesaian Model Pembelajaran Inovatif Progresif.

Jakarta: Kencana. 